Bohemian Waxwing; appeared occasionally.

American Goldfinch; June 3; nesting; common.

Pine Siskin; from June 5 to August 25.

Black Tern; June 4; very common.

Common White Tern; a few observed.

Horned Grebe; June 2; one known nesting pair.

Coot; very common.

Ducks, Mallard, Teal, Canvasback, Ruddy, Pintail; April 6.

Horned Owl; all year round; nesting.

Long-eared $\mathrm{Ow}$; nesting July 14.

Catbird; June 10; quite common.

American Redstart; a flock appeared, August 25.

\section{Silent Wings}

By Doug Gilroy

THE MOST of us know that owls, due to the way their feathers are formed, are very silent fliers. But you never know just how silent, till you have one land on the top of your head.

I was climbing up an ash tree which harboured the nest of a Great Horned Owl. The old owl was nowhere to be seen, so about half way up I paused, standing in a crotch to rest and also to admire the scenery. While I was drinking in this owl'seye view of the country I was suddenly brought back to reality by such a terrific blow on top of the head that it very nearly knocked me off my perch. What in the world struck me! It felt as if someone had dealt me a blow with a coil of rope-yet it flashed through my mind that there was no one else in that tree.

When I looked up, there was Mrs. Owl, just about to land in a tree some distance away, and she was going in a straight line away from me.

I could scarcely believe that it was she who had struck me! Not one sound had I heard to warn me nut even the touching of a twigand she had to fly through several branches to get at me. Now I can fully realize what little chance a small mammal or fowl has. A rabbit is feeding on tender bark. He relaxes a second - wham! - no rabbit!

\section{Baby Birds of 1951}

Elizabeth Barker, Regina

THE 1951 bird nesting season is almost at an end and the birds are moving south again. Many young birds are still accepting handouts from their indulgent parents, while a much larger number are now drifting around alone, or living in larger family groups on a selfsupporting basis.

Taken as a whole it appears to have been the most successful year of my three years residence here in regards to rearing to maturity of young birds, although only a remnant have seemed to survive from each nest in comparison to the given number of eggs laid by each species. It shows, or should show a slight increase in the total bird population if their efforts have been so successful in other places.

Around the yard of my home and in the close vicinity I have noticed. the following; Three broods of Meadowlarks produced a total of four young. A pair of Vesper Sparrows took up residence in the yard. Four or more clay-coloured Sparrows nested close by. The young of Tree Swallows, Common Kingbirds, Arkansas Kingbirds all appeared in my yard and garden. Young Goldfinches and baby Cedar Waxwings have also put in an appearance.

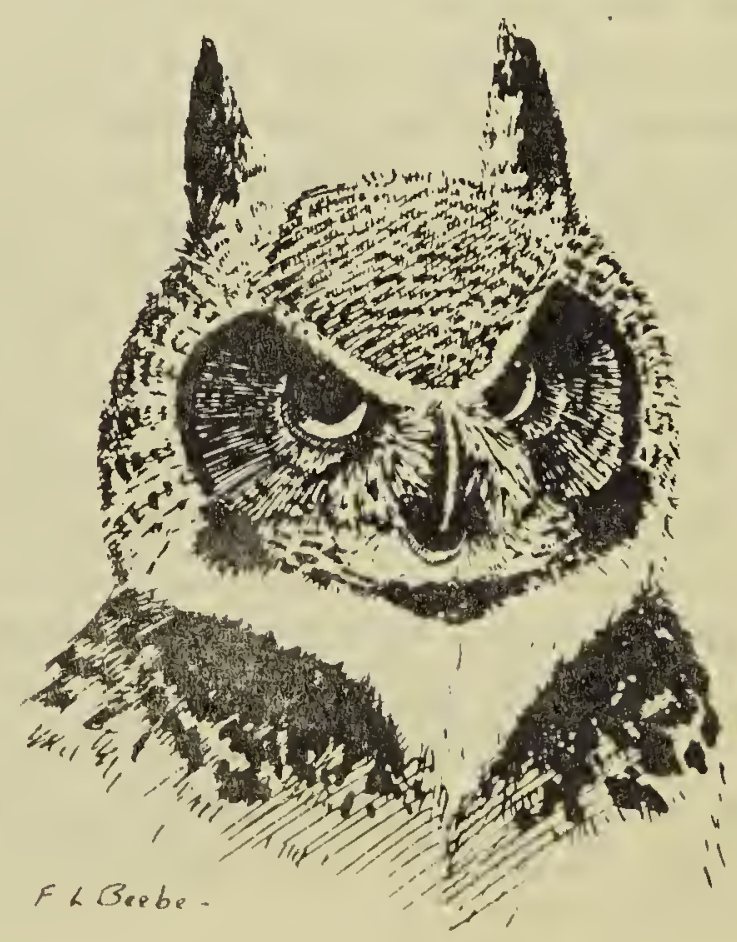

